УДК 346.62

DOI https://doi.org/10.32849/2663-5313/2020.4.15

Наталія Полішук,

аспірантка Інституту економіко-правових досліджень

Національної академії наук України

\title{
КРИПТОВАЛЮТА ЯК ЗАСІБ ПІДВИЩЕННЯ ІНВЕСТИЦИЙНОЇ ПРИВАБЛИВОСТІ УКРАЇНСЬКОГО БІЗНЕСУ: ПРАВОВИЙ АСПЕКТ
}

В умовах підвищеної конкурениії потениіал інновачійного прогресу формує сприятливе середовище для розвитку фінансових технологій. У результаті формуються нові товари і послуги в сфері фінансів, наприклад платформи для інвестицій бізнесу. Такі інновації потениійно можуть вплинути іна державну економіку загалом і результати такого впливу неможливо передбачити. Поява криптовалют і технологій інвестування за допомогою ICО поставили перед державою питання про те, яким чином мають регулюватися такі відносини. Новітні фінансові технології мають свої переваги, однак, у разі відсутності правового регулювання вони формують певні ризики. Актуальність дослідження зумовлена тим, що правовідносини, які виникають під час використання криптовалют для залучення фінансування досі не врегульовані. Стаття присвячена розгляду правового регулювання залучення інвестичійних коштів за допомогою криптовалют. Досліджується можливість фінансування бізнесу шляхом проведення ICO. Описано переваги та недоліки проведення ICO порівняно з традиційними методами залучення інвестииій. Розробляючи норми, що стосуються правового регулювання IСО, украйнському законодавию слід враховувати зарубіжний досвід, тому у статті зроблено огляд правового регулювання ICО в окремих країнах (США, Білорусї), особливу увагу приділено дослідженню правової бази в Свропейському Союзі. Досліджено проєкти, які провели первинне розміщення монет для залучення іноземних інвестииій. Проаналізовано вплив проведення IСО за кордоном на державну економіку. Проаналізовано правову базу Украйни, яка пропонує регулювати криптовалюти та ІСО. Досліджено вплив правової невизначеності статусу криптовалют на проведення IСО проєктів в Украйні. Зроблено висновки щодо перспектив та ризиків проведення ICO, окремо розглянуто випадки проведення ICО з метою відмивання грошових коштів та фінансування тероризму. Окремо було розглянуто проєкт Закону № 2461 «Про внесення змін до Податкового кодексу та інших законів України щодо оподаткування операщій з криптоактивами» від 15 листопада 2019 року. Запропоновано розглянути рекомендаиї з розвитку правового регулювання криптовалют та IСО в Україні.

Ключові слова: ICO, криптовалюти, токен, інвестиції, правове регулювання.

Постановка проблеми. Поява криптовалют і технології блокчейн посприяла розвитку нових фінансових технологій, насамперед це помітно у фінансовому секторі, завдяки чому стало можливим швидке залучення інвестицій. Питання законодавчого регулювання криптовалют гостро постає під час наміру проведення ICO, тому необхідність правового регулювання криптовалют $€$ одним 3 актуальних питань натепер. Проєкти, що залучають інвестиції в приватний сектор, можуть посприяти державній економіці, отримуючи надходження, створити нові робочі місця, стимулювати розвиток підприємництва та підвищити рівень доступу малих і середніх та великих підприємств до фінансування. Але для цього необхідно сформувати правове регулювання, яке відповідає очікуванням індустрії, не створюючи бар'єрів розвитку, та не суперечить міжнародній практиці.
Аналіз останніх досліджень і публікацій. Проблеми правового регулювання ICO та криптовалют досліджують такі вчені, як: М. Бернацький, М. Чайковська, Д. Коваль, Е. Молчанова, Ю. Солодковський та ін. Однак, на відміну від робіт перерахованих авторів, у цій статті розглядається законодавство станом на кінець 2019 року - початок 2020 року, а також аналізується законодавство Європейського Союзу та інші міжнародні нормативно-правові акти, що опублікували роз'яснення, застосовні до сфери криптовалют, протягом останніх двох років.

Метою статті є дослідження перспектив правового регулювання криптовалют для залучення інвестицій у державу та приватний сектор.

Викладення основного матеріалу. Останніми роками з'явився такий новий інструмент 
залучення інвестицій, як ICO "Initial Coin Offering” (первинний випуск монет), форма залучення інвестицій у вигляді продажу інвесторам фіксованої кількості нових одиниць криптовалют, отриманих разовою, або прискореною емісією. Токен може використовуватися для обміну на послугу або товар компанії, яка його випустила, це (utility token) сервісний токен. Наявні також токени, які виконують функцію платіжного засобу (coin token), i (security token) токени, що володіють ознаками цінних паперів [1] Новостворена або наявна компанія випускає власні токени і залучає до інвестицій через продаж цих токенів невизначене коло інвесторів. Метод ICO для залучення інвестицій має сенс для новостворюваних підприємств або державних інноваційних інвестиційних проєктів. ICO швидко вийшло на домінуючі позиції у фінансуванні стартапів, оскільки інвестори сподіваються, що емітовані криптовалюти швидко зростатимуть у вартості, як це трапилось з біткоїном. Через простоту процедури не потрібно нести транзакційні витрати, пов'язані з оформленням паперів, контролем і аудитом фінансування проєкту, не потрібно звітувати про витрачені кошти, як, наприклад, у разі залучення будь-якого іншого фінансування. Перевагами ICO над традиційними методами залучення інвестицій є: 1) високий рівень захищеності та безпеки операцій; 2) усунення посередника (що знижує витрати); 3) надійність - закодовані дані неможливо змінити; 4) прозорість та швидкість транзакцій.

В Україні вже наявні проєкти, які провели первинне розміщення монет для залучення іноземних інвестицій. Інвестиційно привабливими ICO вітчизняними проєктами є DMarket - перший у світі маркетплейс для торгівлі віртуальними (ігровими) предметами, заснований на блокчейні та смарт-контрактах, проєкту вдалося залучити \$19 млн. Також серед відомих проєктів є SocialMedia.Market - перша децентралізована система для пошуку, створення, проведення та аналізу рекламних кампаній. Проєкту вдалося залучили $\$ 8,48$ мільйона. Усі розрахунки в системі відбуваються в криптовалюті, що спрощує перекази, а цим приваблює іноземних інвесторів [2].

Децентралізація процесу сприяє, з одного боку, популяризації такого проєктного фінансування, з іншого боку, створюе ризики як для традиційних державних інститутів, так і для приватних осіб, потенційних інвесторів.

Крім того, з'являється безліч неактивних або невдалих ICO-проєктів. При цьому ризики, які несуть як інвестор, так і влас- ник ICO-проєкту, натепер не враховуються чинним законодавством. Компанія Ernst \& Young (EY) провела дослідження, присвячене ризикам, що пов'язані з інвестиціями в первинне розміщення криптовалют, і визначила, що приблизно 400 млн доларів із 3,7 млрд, які вдалося залучити організаторам випуску криптовалют, були викрадені [3]. Тому відсутність належної перевірки емітентів створює ризики для інвесторів. Також ICO-проєкти можуть використовуватися для фінансування терористичних організацій або відмивання грошових коштів. Для прикладу, в Україні були зафіксовані випадки, коли криптовалюти конвертувалися зловмисниками у гроші, які перераховувалися на тимчасово окуповані терористами території, зокрема на фінансування незаконних збройних формувань бойовиків [4].

У США процедура проведення ICO вже врегульована, і кошти збираються, як і при IPO (первинне публічне розміщення - продаж акцій широкому колу інвесторів). Токени - монети ICO - у Штатах можуть прирівнюватися до цінних паперів чи товарів [5].

Якщо проведення ICO відбувається у державах-членах $\mathrm{CC}$, то компанії зобов'язані звітувати про це Європейському органу з цінних паперів та ринків ESMA (European Securities and Markets Authority), де токени розглядаються як цінні папери. Зокрема, ESMA визначає, що ICO залежно від напряму діяльності мають відповідати законодавству $\mathrm{CC}$, викладеному в чотирьох директивах: Директиві СС 2003/71 від 4 листопада 2003 р. «Про проспекти, що підлягають опублікуванню при відкритій пропозиції цінних паперів або виставленні їх на продаж» (Prospectus Directive); Директиві ЄC 2011/61 від 08 червня 2011p. «Про управляючі фонди альтернативних інвестицій» (AIFMD); Директиві EC 2014/65/EU від 15 травня 2014 року «Про ринки фінансових інструментів» (MiFID); Четвертій Директиві ЄC щодо боротьби з відмиванням грошей (Fourth Anti-Money Laundering Directive) від 20 травня 2015 року «Про запобігання використанню фінансової системи для цілей відмивання грошей або фінансування тероризму» [11]. Зокрема, Директива ЄС про Проспекти визначає необхідність надання достовірної інформації для потенційних інвесторів за допомогою публікації проспекту емісії в разі залучення капіталу, тобто публікація проспекту емісії є обов'язковою вимогою і підлягає обов'язковому схваленню компетентним національним органом держави, в якому проводиться ICO. Директива про ринки фінансових інструментів містить 
правила ліцензування, правила управління продуктом, розкриття інформації до і після продажу. Директива про боротьбу та відмивання доходів, отриманих злочинним способом, містить вимоги щодо проведення аудиту клієнтів, вимоги щодо системи, управління і ведення обліку, повідомлення про підозрілу діяльність.

У Верховній Раді України 15 листопада 2019 року зареєстровано законопроєкт № 2461 «Про внесення змін до Податкового кодексу та інших законів України щодо оподаткування операцій 3 криптоактивами». Законопроєкт вносить зміни не тільки до Податкового, а й до Господарського та Цивільного кодексів України. Термінами, які визначаються, є: «віртуальний актив», «криптоактив», «операція з криптоактивами», «розподілений реєстр», «токен» та «токен-актив» [6].

Згідно із законопроєктом № 2461, «віртуальний актив» - особливий вид майна, який є цінністю у цифровій формі, яка створюється, обліковується та відчужується електронно. До віртуальних активів належать криптоактиви, токен-активи та інші віртуальні активи. «Криптоактив» - вид віртуального активу у формі токена, який створюється, обліковується та відчужується в розподіленому реєстрі та не посвідчує майнових та/або немайнових прав власника криптоактиву; «токен» - електронна одиниця обліку у формі запису в розподіленому реєстрі. Тобто криптовалюти визначаються як майно, яке існує в цифровій формі. У цьому законопроєкті акцент зроблений на оподаткування операцій з криптовалютами, а саме 5 відсотків - ставка податку на доходи фізичних осіб для інвестиційного прибутку від продажу криптоактивів строком на 5 років. Інвестиційний прибуток від операцій 3 криптоактивами розраховується як позитивна різниця між доходом, отриманим платником податку від продажу криптоактиву, та його вартістю, що визначається із суми документально підтверджених витрат на придбання такого криптоактиву та/або на створення такого криптоактиву. Операції з продажу криптоактивів не є об'єктом оподаткування податком на додану вартість [6]. Одразу з'являється питання до законопроєкту, як і чим підтверджувати різницю між доходом і витратами, адже поки відсутня практика, щоб криптобіржі надавали «офіційне» підтвердження придбання криптовалют. I варто зауважити, що для майнінгу це буде один перелік документів, а для доходу, отриманого в результаті трейдингу, має бути інший. Не чітко розподілено сервісні токени як (utility token) ті, які виконують функцію платіжного засобу (coin token), так і ті, які мають бути певним зобов'язанням емітента такого токена (security токен), і їх правова природа.

Одним 3 нещодавніх кроків у напрямі регулювання криптовалют $€$ підписання Меморандуму про співпрацю з питань розвитку українського законодавства стосовно криптовалют між Міністерством цифрової трансформації України та білоруською криптобіржею Currency.com - першою в СНД регульованою біржею криптовалют і токенізованих активів [7]. 3 появою Декрету «Про розвиток цифрової економіки» 32017 р. Білорусь стала, безумовно, цікавою юрисдикцією для ведення бізнесу, пов'язаного з криптовалютами, позаяк зараз число резидентів Парку високих технологій досягло 454 компаній, на момент підписання Декрету було всього 192 резиденти, а прибуток для держбюджету - приблизно 350 млн доларів [8].

\section{Висновки}

Такі переваги ICO-проєктів, як прозорість, швидкість операцій, достовірність та незмінність даних, високий рівень безпеки операцій, мають великі перспективи. Це дає ліквідність ринку і економічний потенціал для держави, створює додаткові канали для залучення інвестицій в Україну, але за обережного правового регулювання. Натепер законодавство України поки що не визначило правовий режим криптовалют, що суттєво впливає на можливість проведення таких ICO-проєктів легально. Однак поява Законопроєкту № 2461 та Меморандуму про співпрацю з білоруською криптобіржею показує, що держава має намір прогресувати в напрямі правового регулювання криптовалют.

Для успішного розвитку ICO-проєктів необхідно прийняти та затвердити Законопроєкт «Про внесення змін до Податкового кодексу та інших законів України щодо оподаткування операцій 3 криптоактивами», адже він закріпить правовий статус токенів та криптовалют як об'єктів цивільного права, сприятиме залученню інвестицій, а держава отримає додаткові надходження від таких операцій 3 криптовалютами. Однак потрібно доопрацювати та уточнити деякі моменти, а саме:

1) окремо виділити токени, які у разі проведення ICO надають право управління компанією та право на отримання частини прибутку компанії як цінні папери, а не як нематеріальні активи;

2) встановити чіткі вимоги щодо прозорості випуску криптовалют, адже про «майнінг» криптовалют у законопроєкті не йдеться, але зазначено, що витрати на 
«створення» криптоактивів враховуються під час розрахунку фінансового результату нарівні з витратами на їх придбання;

3) для усунення ризиків відмивання доходів та фінансування тероризму потрібно врахувати досвід $\mathrm{CC}$, а саме включити вимогу щодо обов'язкової ідентифікації у разі проведення ICO як інвесторів, такі власників проєкту (емітентів криптовалют);

4) доповнити законопроєкт № 2461 нормою про порядок проведення ICO, в тому числі про порядок випуску токена емітентом;

5) додати уточнення, на якому саме етапі буде відбуватись оподаткування проведених операцій з криптовалютами та токенами: чи на етапі продажу криптовалют на біржі, чи у момент виведення криптовалюти у фіатні кошти;

6) переглянути момент «документального підтвердження витрат придбання криптовалют» для подальшого оподаткування, адже натепер жодна криптовалютна біржа не надає таких підтверджуючих документів.

\section{Список використаних джерел:}

1. ICO (криптовалюти). Вікіпедія: вільна енциклопедія. URL: https://uk.wikipedia.org/wiki/ ICO (криптовалюти (дата звернення: 09.03.2020).

2. ТОП-5 українських ICO-проєктів. URL: https://cryptota.com.ua/top-5-ukrainskykh-icoproektiv/ (дата звернення: 09.01.2020).

3. Махінчук B.M. До питання правового регулювання криптовалюти (аналіз закордонного досвіду). IUS PRIVATUM. № 1, 2018. С. 32-45.

4. Молчанова Е. Глобальна сервісна природа сучасних криптовалют / Е. Молчанова, Ю. Солодковський. Міжнародна економічна політика. 2014. № 1. C. $60-79$.

5. U.S. Securities Laws May Apply to Offers, Sales, and Trading of Interests in Virtual Organizations. URL: https://www.sec.gov/news/ press-release/2017-131.
6. Big risks in ICO market. URL: https:// www.ey.com/Publication/vwLUAssets/Big Risks in_ICO_market/\$FILE/18012546596\%20ICO $\% 20$ market\%20infographic\%20v11 SCORE\%20 Approved_FINAL_JAN\%2017\%202018.pdf (дата звернення 03.01.2020).

7. Потреба визначення статусу криптовалют в Україні: економічні та кримінальні процесуальні аспекти. URL: http://nbuv.gov.ua/ j-pdf/muvnudp_2018_1-2_31.pdf (дата звернення 30.01.2020).

8. Про внесення змін до Податкового кодексу України та деяких інших законів України щодо оподаткування операцій 3 криптоактивами : Проєкт Закону України від 18.11.2019 № 2461. URL: $\quad$ http://w1.c1.rada.gov.ua/pls/zweb2/webproc 4 1?pf3511=67423 (дата звернення 10.02.2020).

9. Мінцифра розпочала співпрацю 3 однією 3 найкрупніших криптовалютних бірж у світі. URL: https://thedigital.gov.ua/news/mintsifrarozpochala-spivpratsyu-z-odnieyu-z-naykrupnishikhkriptovalyutnikh-birzh-u-sviti (дата звернення 08.01.2020)

10. Минцифры договорилось о сотрудничестве с белорусской криптобиржей Currency.com в вопросах разработки украинского законодательства по IT и криптовалютам. URL: https://itc.ua/ news/minczifry-dogovorilos-o-sotrudnichestve-sbelorusskoj-kriptobirzhej-currency-com-v-voprosahrazrabotki-ukrainskogo-zakonodatelstva-po-it-i-kriptovalyutam/ (дата звернення 10.01.2020).

11. IFRS 9 Financial Instruments. URL: http:// www.ifrs.org/issued-standards/list-of-standards/ ifrs-9-financialinstruments/ (дата звернення 30.12.2019)

12. Пресс-служба Еврокомиссии. URL: http://europa.eu/rapid/press-release_IP-18-521 en.htm (дата звернення 10.01.2020).

13. Тест Howey: когда токен можно считать ценной бумагой. Принципы разработки и продажи блокчейн-токенов. Интернет-сайт medium. com. URL: https://medium.com/digital-finance-ru/ тестhowey-когда-токен-можно-считать-ценнойбумагой-b3e1a44f4d16 (дата звернення: 08.12.2019).

In a highly competitive environment, the potential for innovative progress forms a favourable environment for the development of financial technologies. As a result, new products and services in the financial sector, such as business investment platforms, are formed. Such innovations can potentially affect the state economy as a whole, and the effects of such an impact cannot be predicted. The emergence of cryptocurrencies and investing technologies with the help of ICO have raised the question of how such relations should be regulated. New financial technologies have their advantages, however, in the absence of legal regulation, they pose some risks.

The article deals with the legal regulation of attracting investment funds using cryptocurrencies. The possibility of financing a business through an ICO is being explored. The purpose of the article was to analyse the advantages and disadvantages of the ICO in comparison with traditional methods of attracting investment. The relevance of research is due to the fact that the legal relationships that arise when using cryptocurrencies to attract financing are still not settled.

Developing norms regarding ICO regulation Ukrainian law should take into account foreign experience, so the article gives an overview of ICO regulation in individual countries (USA, Belarus), special attention is paid to the study of the legal framework in the European Union. The projects that carried out the initial placement of coins to attract foreign investment were investigated. Influence of holding of ICO abroad on the state economy is analysed. 
Analysed the current legal framework in Ukraine aimed at regulating the turnover of cryptocurrency and ICO. This article discusses the problems of legal uncertainty regarding the cryptocurrency and ICO in Ukraine. Conclusions on the prospects and risks of ICOs have been drawn, and cases of ICOs for money laundering and terrorist financing have been separately considered. It is proposed to consider amendments to the current legislation on the legal status of cryptocurrencies and ICOs in Ukraine.

The draft Law No. 2461 "On Amendments to the Tax Code and Other Lawes of Ukraine on Taxation of Operations with Crypto-Assets” of November 15, 2019 was considered separately.

Key words: ICO, cryptocurrencies, token, investment, legislative regulation. 